\title{
Regulatory Capitalism, Globalization and the End of History
}

Peter DRAHOS $^{1}$

\section{Introduction}

Regulatory capitalism is a capitalist order in which actors, both state and non-state, use a wide array of techniques to influence market behaviour. ${ }^{2}$ Many actors find themselves in regulatory relationships, relationships in which they are sometimes the regulator and in other contexts the regulatee. Regulatory capitalism is characterized by webs of relationships and interactions that produce what scholars within the University of Hokkaido Global COE program term 'multi-agential governance'. ${ }^{3}$ The globalization of regulation has seen many more regulatory states become 'regulatees' in various domains, meaning they have taken on standards set elsewhere. ${ }^{4}$ Comparatively few states can claim to have been standard-setters as opposed to standard-takers in the process of regulatory globalization.

\footnotetext{
${ }^{1}$ Professor at the Regulatory Institutions Network, Australian National University and Chair in Intellectual Property, Centre for Commercial Law Studies, Queen Mary, London University. This paper is based on a talk given at the 'Establishing a New Global Law and Policy for Multi-Agential Governance' conference, Hokkaido University, Japan, 24-25 November 2012. My thanks go to Professor Takeshi Fujitani and all the other participants for their questions and comments. My thanks go to Professor Yoshiyuki Tamura for encouraging me to write this paper.

${ }^{2}$ For a general account see J. Braithwaite, Regulatory Capitalism: How It Works, Ideas for Making it Work Better, Cheltenham, Edward Elgar, 2008.

${ }^{3}$ For details about the COE program and the members who have contributed to the development of multi-agential governance see http://lex.juris.hokudai.ac.jp/ gcoe/index_e.html.

${ }^{4}$ See J. Braithwaite and P. Drahos, Global Business Regulation, Cambridge University Press, 2000, ch. 20.
} 
Using as point of departure the study of regulatory globalization that I conducted with my colleague John Braithwaite, which was published in 2000 under the title of Global Business Regulation (GBR), I want to focus on the rise of Brazil, Russia, India, China and South Africa (BRICS) as agents of regulatory globalization rather than as emerging markets. Section 2 of this paper distinguishes regulatory globalization from economic globalization. Our study looked at more than 20 domains of business regulation, with the bulk of our 500 interviews conducted in the period of 1990-1995. The rise of the BRICS became much more pronounced after this period. The issue, which occupies section 3 of this paper, is whether this rise in economic power has also brought with it a commensurate rise in the capacity of the BRICS to set global regulatory agendas and to globalize regulatory norms. For reasons that will become clear in section 4 of the paper, regulatory capitalism can be plausibly characterized as a more adaptive form of capitalism than previous capitalist orders. However, regulatory capitalism does face a huge challenge in the achieving the optimal regulation of the natural cycles and processes (for example, the carbon cycle, the water cycle, the nitrogen cycle) that make up what many scientists now call the earth system. The economic growth of the BRICS has increased the regulatory complexities of this challenge since, not surprisingly, these states are following much the same strategies as developed countries on the use of fossil fuels and the conversion of their natural capital into other forms of capital. In this section of the paper I suggest that regulatory capitalism continues along the path of earlier capitalisms in operating with property right systems that allow the social benefits of natural or public good assets to be diminished or destroyed. Earth systems science continues to produce evidence that despite its rich array of techniques and pockets of sustainable development success, regulatory capitalism continues to fail to put in place the preservationist duties needed to support an earth system on which regulatory capitalism depends. 


\section{Globalization}

Globalization was one of the buzz words of the 1990s. But almost as soon as it buzzed into the social sciences, it provoked a sceptical reaction. $^{5}$ On one view globalization referred to processes of economic integration in which national markets were becoming a part of regional or global markets, markets in which multinational firms were dominant players. The capacity of states to influence these markets was seen as radically diminished. However, it soon became clear that the economic data could be made to tell different stories. Technical debates arose around whether the indicators used to measure globalization, such as the rising ratio of merchandise exports to GDP using constant prices as a measure, exaggerated the effects of globalization. ${ }^{6}$ Similarly, depending on how one defined multinational corporation there were either tens of thousands (based on a firm with one or more foreign subsidiaries) or very few (based on a firm with an integrated chain of global production). The clearest area of globalization was the financial sector where cross border financial flows between banks and investment in bonds and equities had increased dramatically in scale. Even here, however, in the very heartland of globalization there were and are stark country differences. For example, expressing foreign assets and liabilities as a ratio to GDP, Lane points out that advanced economies went from $68.4 \%$ in 1980 to $438.2 \%$ in 2007 , while emerging markets in the same period went from $34.9 \%$ to $73.3 \%{ }^{7}$ In other words, the cross-border financial integration of the latter group was considerably less.

\footnotetext{
${ }^{5}$ See, for example, P. Hirst and G. Thompson, 'The future of globalisation' in Michie, J. (ed.), The Handbook of Globalisation, Cheltenham, UK, Edward Elgar, 2003, 17.

${ }^{6}$ For a discussion of this and other indicators see B. Sutcliffe and A. Glyn, 'Measures of globalization and their misinterpretation' in Michie, J. (ed.), The Handbook of Globalisation, Cheltenham, UK, Edward Elgar, 2003, 61.

${ }^{7}$ See P.R. Lane, 'Financial Globalization and the Crisis', BIS Working Papers, No. 397 (2012), 3, available at http://www.bis.org/publ/work397.pdf.
} 
These debates about globalization showed that it was a set of processes rather than just one process of integration and interconnection. One way in which to separate these processes is to think about the globalization of markets, the globalization of firms and the globalization of regulation. ${ }^{8}$ These are distinct processes with contingent rather than necessary connections amongst them. For example, markets can globalize even though national regulation remains in place. Online marketplaces such as Amazon, eBay and Taobao are examples of substantially globalized marketplaces that are still regulated nationally. The globalization of regulatory standards may end up impeding the integration of national markets. For example, the World Trade Organization's agreements on phytosanitary standards and technical barriers to trade were intended to create some convergence of standard-setting in these areas, the goal of this convergence being to facilitate trade. ${ }^{9}$ But the evidence suggests that developing countries face problems in achieving the level of scientific capability required by these standards. ${ }^{10}$ The upshot is that developing countries can lose rather than gain markets as a result of the standards. The globalization of firms can take place in the absence of the globalization of markets or regulatory standards. Pharmaceutical multinationals such as Pfizer and GlaxoSmithKline operate in prescription drug markets that are still regulated at the national level on matters such as price. Australia, for example, regulates the cost of some patented medicines to citizens through its Pharmaceutical Benefits Scheme.

\footnotetext{
${ }^{8}$ J. Braithwaite and P. Drahos, Global Business Regulation, Cambridge University Press, 2000, 8-9.

${ }^{9}$ The Agreement on Technical Barriers to Trade and the Agreement on Application of Sanitary and Phytosanitary Measures.

${ }^{10}$ See P. Athukorala and S. Jayasuriya, 'Food Safety Issues, Trade and WTO Rules: A Developing Country Perspective' in Mehta, R. and George, J. (eds.), Food Safety Regulation Concerns and Trade: The Developing Country Perspective, Delhi, Macmillan India, 2005, 24.
} 


\section{The BRICS as Regulatory Powers}

One of the conclusions of GBR is that the US state has been the most influential actor in accomplishing the globalization of regulation in a variety of fields including nuclear power regulation (its role in the formation of the International Energy Agency), financial regulation (a manifold influence through, for example, Wall Street innovation and the IMF), intellectual property (its influence in bringing intellectual property standards into the trade regime), competition law (the export of anti-trust principles after World War II to countries such as Germany) and the regulation of illicit drugs (its support for prohibition and its capacity to influence in various ways other countries to take the same approach). We also found the European Commission beginning to rival the US level of influence. Large US corporations have played a vital role in this global regulatory story. The US state and US multinationals have at various points in history been allies in global regulatory agendas in domains such as telecommunications, financial services (where they have supported the principle of deregulation) and intellectual property (where they have supported the principle of regulatory intervention in markets of information). Through these alliances the US state and US multinationals have pooled forms of power and expertise making them formidable opponents in regulatory contests. US multinationals can, for example, through the juridical prowess of their many lawyers provide the US state with detailed critiques of the shortcomings of a developing state's intellectual property law. Using this information, the US government can threaten trade sanctions against that state. It is this capacity to deploy combinations of hard and soft power that has made the US such a central player in the globalization of regulation.

Although economic power is obviously an important factor in a state's capacity to be a generator of regulatory influence, such influence does not automatically flow from economic power. The power to influence the course of regulation at the global level has to be assembled, assembled into inner circles of consensus that draw in the next-most-important layers until the principal resisters come to see their isolated resistance as 
futile. For example, on matters such as telecommunications deregulation the US and US corporations start the construction of an inner circle drawing in EU partners, often beginning with the UK. An economically powerful state that is not able to forge these wider circles of consensus may have comparatively little influence on the direction in which global regulation travels, the case of Japan in the second part of the twentieth century being the best example of this claim. ${ }^{11}$ Putting the point another way, in a multi-agential world, the possession of economic power alone is not enough to secure regulatory influence.

The acronym 'BRIC' was coined by Jim O'Neill of Goldman Sachs to draw attention to the real GDP growth of Brazil, Russia, India and China, a growth that O'Neill suggested would require a re-organization of international policy fora such as the G7. ${ }^{12}$ The membership of these fora had to take into account that the relative economic weight of these four countries justified their much greater inclusion in international economic planning processes. Based on a weighting of GDP using Purchasing Power Parity, O'Neill showed that in 2000 China was already the second biggest economy behind the US, with India, Brazil and Russia coming in at $4^{\text {th }}, 9^{\text {th }}$ and $10^{\text {th }}$ respectively. If we switch to a ranking based on nominal GDP in 2012, then China and the US stay the same with India, Brazil and Russia coming in at $10^{\text {th }}, 7^{\text {th }}$ and $9^{\text {th }} \cdot{ }^{13}$ O'Neill's basic insight about the emergence of the BRIC countries as economic powers remains intact.

But to what extent have the BRICs, along with other economies such as South Africa and Indonesia emerged as leaders of global regulatory agendas that have concrete manifestations as principles or rules that have spread as regulatory models from these states to other parts of the world?

${ }^{11}$ J. Braithwaite and P. Drahos, Global Business Regulation, Cambridge University Press, 2000, 27.

12 See J. O'Neill, 'Building Better Global Economic BRICs', Global Economic paper No. 66, Goldman Sachs (2001) available at http://www.goldmansachs.com/ our-thinking/archive/archive-pdfs/build-better-brics.pdf.

${ }^{13}$ Based on World Bank data. See http://databank.worldbank.org/data/download/ GDP.pdf. Accessed on 21 October 2013. 
Clearly, this is much too big a question to be able to answer in one short paper, but it is important to stress that it is a separate question from the rise of these countries as economic powers. In the second part of the twentieth century Brazil and India in particular were leaders of developing country agendas, with UNCTAD functioning as a think tank and discourse broadcaster for the developing countries. Under the leadership of these countries UNCTAD had some modest successes such as the creation of the Generalized System of Preferences within the General Agreement on Tariffs and Trade (GATT) and the passage as non-binding UN recommendations of the General Assembly of multilaterally agreed principles and rules for the control of restrictive business practices. ${ }^{14}$ On the other side of the regulatory contests of the first few decades after World War II, developed country leaders such as the US and UK had the benefit of the OECD as a discourse broadcaster. This, along with the capacity of these states to create networks of consensus in fora such as the GATT, led to the proliferation of Western regulatory models in developing countries in many domains including intellectual property and the regulation of services (via the General Agreement in Trade in Services). These regulatory models continue to have profound effects on the domestic economies of many developing countries.

Looking at the first decade of the $21^{\text {st }}$ century there are some signs that the BRICS may be, both individually and collectively, more effective as veto coalitionists capable of stopping regulatory agendas not to their liking. An example of this is the leadership of Brazil, India and South Africa of the G20, a coalition of developing countries that was formed in 2003 at the WTO Ministerial meeting in Cancun in the context of the Doha Development Round. The G20 rejected the proposals being made by the US and EU on trade in agriculture at that meeting. What the G20 did in the words of Brazil's ambassador to the US at the time 'was question for the first time the duopoly of the European Union and the United

\footnotetext{
14 J. Braithwaite and P. Drahos, Global Business Regulation, Cambridge University Press, 2000, 194-195.
} 
States in the WTO system'. ${ }^{15}$ During the Uruguay Round, the US and EU (with some assistance from Japan and Canada) had steered through a package of agreements that did little in terms of free trade for developing countries in key areas such as textiles and agriculture while at the same time enhancing the monopoly rent-seeking capacities of their own corporations through the Agreement on Trade-Related Aspects of Intellectual Property Rights. Twelve years on into the Doha Round, it is clear that the EU and US cannot individually or together push through agreements that are seen as unfair by the major developing countries. The response of the US and EU to this challenge to their rule-making power has been to defect to trade bilateralism, a defection that has been copied by traditional supporters of multilateralism such as Australia and Japan. The effect has been to undermine the public good of multilateral trade.

O'Neill's analysis of the BRIC countries in 2001 did not depict them as a political coalition bent on changing the rules of global regulatory games, but rather as economic entities united by growth rates that would see them become dominant markets in the global economy. However, since O'Neill's analysis the BRIC countries have moved in the direction of coalitional status and looked to deepen cooperation amongst themselves. The BRIC countries held their first summit in June of 2009 in Russia and included South Africa in their third summit in China in 2011, thereby becoming the BRICS. The BRICS, one might say, have become a bloc. These summits have progressively widened to include ministerial meetings in areas such as finance, trade, health and agriculture.

One great test of the BRICS' cohesiveness and regulatory leadership lies in the area of international financial regulation. The architecture of the international financial system can be thought of as a network with three critical nodal points serving to tie together many of the vast number of players in the network. The three nodal points are the Bretton Woods

\footnotetext{
${ }^{15}$ Cited in J. Maswood, 'Developing countries and the G20 in the Doha Round' in Crump, L. and Maswood Javed, S. (eds.), Developing Countries and Global Trade Negotiations, London and New York, Routledge, 2007, 41, 53.
} 
institutions of the IMF and the World Bank, the Bank of International Settlements (BIS) and the $\mathrm{G}$ (x) group where $\mathrm{x}$ represents the number of countries seen in a given period to be central to international monetary coordination. After the US abandoned the convertibility of the dollar in 1971, cooperation on international monetary matters drifted into meetings of finance ministers of the G5 and G7. Today the G7 has grown into the G20.

The consequences of the financial crash of 2007-08, with its beginnings in the US mortgage market and subsequent impact on inter-bank lending affected most the economies of the world, including the BRICS. Predictably, the reform of international financial institutions has become a persistent theme in the joint statements of the BRICS.

For present purposes it is important to point out that well before the crash of 2007-08 the BRICS had joined the nodal centres that exercise some regulatory influence over the networks of global financial capitalism. During the $1990 \mathrm{~s}$, the BRICs became members of the BIS. ${ }^{16}$ Formed in 1930, the BIS is the single most important forum for cooperation amongst central banks. In 1996 the Board of Directors of the BIS invited the central banks of Brazil, India, China and Russia to join by subscribing for shares. The BIS also acts as the secretariat for the Basel Committee on Banking Supervision (Basel Committee). Formed in 1974 by the central bank governors of the G10 in response to banking closures in Germany and the US in that year, the Basel Committee is the principal international forum for cooperation on matters of banking supervision. In 2009 the Basel Committee expanded its membership, including, amongst others, the BRICS. ${ }^{17}$ While this membership of the BRICS comes after the financial crisis of 2007-08, the Basel Committee was engaging with some of the banking supervisory authorities from the BRICS, most notably China during the 1990s. The BRICS were also all members of the IMF before the 2007-08 crisis. Brazil, India, China and

\footnotetext{
${ }^{16}$ For the dates see http://www.bis.org/about/chronology/1990-1999.htm.

${ }^{17}$ See http://www.bis.org/press/p090313.htm.
} 
South Africa were original members of the IMF, signing the Articles of Agreement in 1945 (with the People's Republic of China taking on those IMF responsibilities in 1980). Russia joined in 1992.

By the time of East Asian financial crisis of 1997-1998, there was a broader realization that membership of the $\mathrm{G} 7$ had to be deepened if international financial stability was to become something more than an outbreak between recurring financial crises. At a meeting of finance ministers of the G7 in 1999, the goal of including 'systematically important countries' in an 'informal mechanism of dialogue' was announced. ${ }^{18}$ This led to the formation of the G20 (not to be confused with the G20 coalition of developing countries in the WTO that was discussed earlier). ${ }^{19}$ These systematically important countries included Argentina, Australia, Brazil, China, India, Mexico, Russia, Saudi Arabia, South Africa, Korea, and Turkey. The G20 became a much more prominent node of global policy deliberation when President George Bush in November of 2008 invited the leaders of G20 countries to a summit to help coordinate a response to the consequences of the US financial crisis. Today the G20 is the single most important $\mathrm{G}$ forum for policy dialogues on matters of international economic coordination.

One can see that all the BRICS hold memberships in the most important nodal governance centres of finance capitalism and in some cases have done so for longer than might be thought. The question, which only time will answer, is whether they can turn this membership into a force for change. If one looks at the history of these nodal centres on matters such as voting rights and headship there is a certain whiff of the US-EU duopoly that had characterized the GATT and the early days of the WTO. It is only in the last decade that the BRICS have genuinely contested this duopoly in the WTO. In the case of the network architecture for global

\footnotetext{
${ }^{18}$ See 'Report of G7 Finance Ministers to the Koln Economic Summit', 18-20 June 1999, available at http://www.library.utoronto.ca/g7/finance/fm061999.htm. ${ }^{19}$ For the detailed history of the G20 prepared by a study group of the G20 see The Group of Twenty: A History (2008) available at http://www.g20.utoronto.ca/.
} 
financial regulation, the BRICS will have to become a creative coalitional force if they are to bring changes that reflect the policy goals emanating from their joint summits.

On the reform of this architecture it is worth remembering that Japan in the midst of the East Asian Financial Crisis launched a proposal for an Asian Monetary Fund (AMF). Japan's reasoning in suggesting a regional lender of last resort was based on the geo-political reality that an IMF operating under an US hegemony might not act in a way that was consistent with the interests of the Asian countries most severely affected by the crisis. ${ }^{20}$ Japan had strong incentives to act because, amongst other things, its banks were heavily exposed in terms of loans to countries such as Thailand. Moreover, Japan's financial policy elites had a better analysis of the region's problems than the IMF because of Japan's long investment and close ties to the countries in the region. Japan's initiative ran into severe criticism from US officials who saw it as threat to the IMF's dominance. Japan found itself engulfed in a hardball politics in which, according to one of the key initiators of the AMF proposal, Eisuke Sakakibara, the US used the promise of extra IMF quotas to lure some Asian countries away from supporting Japan's initiative. ${ }^{21}$ Critically, China fell into silence on the matter.

Japan's AMF initiative may have disappeared into the alleyways of technocratic history, but the basic logic of the Japanese position should be reflected upon by the BRICS. A regional lender of last resort equipped with good data and analysis of the regional economies for which it has responsibilities offers those countries a way to insulate themselves from the effects of a global financial architecture that remains centralized around nodes that continue to operate under an EU-US duopoly. It is true that voting power on the IMF has changed as a result of the imple-

\footnotetext{
${ }^{20}$ For an account of the reasons behind Japan's initiatives see P.Y. Lipscy, 'Japan's Asian Monetary Fund Proposal', Stanford Journal of East Asian Affairs, 3 (2003), 93.

${ }^{21}$ See P.Y. Lipscy, 'Japan's Asian Monetary Fund Proposal', Stanford Journal of East Asian Affairs, 3 (2003), 93, 96.
} 
mentation of the 2008 Quota and Voice reforms and that further changes will flow once the changes agreed to in 2010 come into force. ${ }^{22}$ A table prepared by the IMF shows that after the 2010 reforms the $\mathrm{G} 7$ will command $41.2 \%$ of the vote, with the US holding $16.5 \%{ }^{23}$ China (6\%), Russia $(2.6 \%)$, India (2.6\%), Brazil (2.2\%) and South Africa (0.6\%) together hold $14 \%$. While the aim of the IMF voting reforms was to give more representation to emerging and lower-income countries, an important question is whether these reforms do much to change coalitional power within the IMF. The G7 as a bloc has $41 \%$ as its starting point and the US begins with $16.5 \%$, the latter being an especially useful percentage if one is a veto coalitionist. (While the IMF largely follows a practice of consensus there are special majority rules for some categories of decision-making, these rules requiring either an $85 \%$ or $70 \%$ majority. ${ }^{24}$ ) The fact that there is a very long tail of countries in the IMF's 188 membership, each with a very small fraction of voting power means that countries or blocs that start with the kind of percentages possessed by the US or G7 have a huge advantage in IMF vote-buying games.

The crisis of 2007-08 revealed in the US a deeply troubling level of crony financialism implicating banks, ratings agencies, regulators, accounting firms, financial services firms and last but not least academic consulting services from prestigious US universities. ${ }^{25}$ Rather than carrying out

\footnotetext{
${ }^{22}$ For a description of these reforms see http:/www.imf.org/external/np/sec/pr/ 2011/pr1164.htm.

${ }^{23}$ See the Table entitled 'Quota and Voting Shares Before and After Implementation of Reforms Agreed in 2008 and 2010 (In percentage shares of total IMF quota)' available at http://www.imf.org/external/np/sec/pr/2011/pdfs/quota_tbl.pdf. ${ }^{24}$ For a detailed analysis of the rules see P. Brandner, H. Grech and I. Paterson, 'Unifying EU Representation at the IMF Executive Board: A Voting and Veto Power Analysis', Institute for Advanced Studies, Vienna, 2009, available at http://www.ihs.ac.at/publications/eco/es-245.pdf.

${ }^{25}$ If my hypothesis of crony financialism is correct then it follows that the capacity of government to bring stability to an unstable financial system is reduced. For a model of financial capitalism's recurrent crises that draws on the insights of Minsky's financial instability hypothesis see S. Keen, 'Finance and Economic
} 
their various regulatory and fiduciary duties as independent agents, these actors became a network united in extracting ever higher levels of rents from the financial system. Emblematic of this crony network was the behaviour of the ratings agencies such as Moody's and Standards and Poor's that maintained AA ratings for Lehman Brothers just before it collapsed. ${ }^{26}$ The Obama Administration has left the reform of this crony financialism largely untouched. Rather, US financial authorities have focussed on bailing it out through quantitative easing procedures that have now created what is probably the greatest moral hazard problem yet seen in financial regulation.

For BRIC countries there is both an opportunity and an imperative to consider mechanisms of strategic insulation from a global financial network in which more shocks are likely to emanate from the US and/or the EU. Perhaps in a world where there was a truly independent global lender of last resort of the kind envisaged by Keynes at the negotiations at Bretton Woods, it might make sense for countries to invest in strengthening that lender. However, in the end, the decisions of the IMF are the product of voting games, ones in which the US and the G7 start with considerable advantages. The fact that the voting field is tilted in favour of the US, along with its domestic political failure to reform its system of crony financialism means that countries should be looking at ways to insulate themselves from future shock waves of instability that have their epicentre in the US.

There are some signs of this thinking emerging. East Asian countries after the financial crisis of 1997 concentrated on the accumulation of

Breakdown: Modeling Minsky's "Financial Instability Hypothesis", Journal of Post Keynesian Economics, 17 (1995), 607.

${ }^{26}$ S. Nasiripour, 'Credit Rating Agency Analysts Covering AIG, Lehman Brothers Never Disciplined', Huffington Post, 11/30/09, available at http://www. huffingtonpost.com/2009/09/30/credit-rating-agency-anal_n_305587.html. 
reserves in order to reduce their future dependence on the IMF. ${ }^{27}$ The BRICS at their most recent summit in South Africa in 2013 agreed to the establishment of a BRICS development bank, as well as a contingent reserve arrangement of $\$ 100$ billion for the purpose of dealing with liquidity problems. ${ }^{28}$ These are admittedly small steps, but when one adds it to other initiatives such as the growth of bilateral swap arrangements by Asian countries and initiatives to move away from denominating trade deals in US dollars one can see, putting it in networks terms, that the smaller nodes within the financial network are strengthening or creating new ties as well talking about the creation of new nodes to help them achieve stability in their part of the network. ${ }^{29}$ It seems unlikely given the extent of US hegemony in the current network architecture that it can lose influence in the $21^{\text {st }}$ century in the way that the UK quickly lost influence over the global financial system after reaching the apogee of its sterling-based influence at the beginning of the $20^{\text {th }}$ century. What we are seeing for the moment are signs that point to a potential decentring of the US role in the current global network, something that may ultimately bring more stability to the network. The deeper point is that the BRICS form an integrated part of a global financial regulatory network not of their making and moreover they have helped through capital contributions to strengthen the IMF and BIS. They have yet to take on the kind of steering role that has characterized US hegemony of this domain of regulation.

${ }^{27}$ W. Thye Woo, 'China and international financial reform' in Garnaut, R., Song, L. and Woo Thye, W. (eds.), China's New Place in a World of Crisis, Canberra, Australia, ANU E Press, 2009, 15, 19.

${ }^{28}$ See http://www.brics5.co.za/.

${ }^{29}$ The US dollar is widely used in the invoicing of trade. More countries would like to move to local currency invoicing, but this requires them to liberalize foreign exchange controls. See M. Auboin, 'Use of Currencies In International Trade: Any Changes in the Picture?', WTO, Staff Working Paper, ERSD, 201210, available at http://www.wto.org/english/res_e/reser_e/ersd201210_e.pdf. 


\section{Property Rights in Regulatory Capitalism}

The rise of the BRICS along with other emerging market economies can be located within the context of the broader phenomenon of regulatory capitalism. ${ }^{30}$ In regulatory capitalism the state is both a regulator and regulatee (subject to regulation by non-state actors such as ratings agencies). In its capacity as regulator it adopts a mixed method approach in terms of choice of regulatory instruments - direct command and control models based on the coercive use of rules, the use of independent regulatory agencies to regulate privatized assets, the facilitation of selfregulation, the use of smart techniques of regulation to encourage business evolution towards social goals (for example, the use of best available technology standards to meet environmental objectives) and allowing for the use regulation by information (for example, labelling that allows for consumer preferences to work as demand forces). Over the years different theories of regulation such as enforced self-regulation, responsive regulation, smart regulation, meta-regulation have captured different dimensions of the practice of regulation by states and non-state actors. ${ }^{31}$ Theorists who have looked at these practices in aggregate see in them a distinctive capitalist order in which the state does more steering and nonstate actors, such as NGOs, do more rowing. The number of international NGOs went from about 200 at the beginning of the $20^{\text {th }}$ century to

\footnotetext{
${ }^{30}$ For an application of the concept to a variety of areas see D. Levi-Faur and J. Jordana (eds.), The Rise of Regulatory Capitalism: The Global Diffusion of a New Order, The Annals of the American Academy of Political and Social Science, 598, 2005.

31 There are many important landmarks and contributions to this regulatory literature including, J. Braithwaite, 'Enforced self regulation: a new strategy for corporate crime control', Michigan Law Review, 80 (1982), 1466; I. Ayres and J. Braithwaite, Responsive Regulation: Transcending the Deregulation Debate, New York and Oxford, Oxford University Press, 1992; N. Gunningham and P. Grabosky, Smart Regulation: Designing Environmental Policy, Oxford, Clarendon Press, 1992; P. Grabosky, 'Using Non-governmental resources to foster regulatory compliance', Governance: An International Journal of Policy and Administration, 8 (1995), 527.
} 
about 4000 in $1980 .^{32}$ At the beginning of the $21^{\text {st }}$ century various figures point to a large and global NGO sector involving hundreds of thousands of NGOs with millions of people participating in them. ${ }^{33}$

The wide array of actors and techniques that constitute this new order of capitalism appear to make capitalism more resilient, more adaptive, better at managing risks. ${ }^{34}$ There are many examples of how regulation has improved the lives of people, obvious ones being improvements in food and drug regulation, regulation of car safety standards, the use of competition law to break up cartels, the regulation of health professionals, the regulation of worker safety in industries such as mining and so on. Regulatory capitalism features many webs of relationships through which regulatory initiatives can potentially travel and have a concrete impact. For example, a consumer in a Western country may be interested in purchasing a handmade rug, but not one made by a five year old girl forced to work fourteen hours a day, in conditions that will cause her physical deformity and shorten her life. When it comes to circumstances of production many consumers want to see a fair wage being paid, safe conditions of work, the use of a production process that minimizes environmental damage and so on. The cost to each individual consumer of tracing a retailer's international supply chain to ascertain the truth about the circumstances of production is high. The individual consumer also faces a collective action problem. One individual making the decision not to purchase the rug will have little impact on the market. Many coordinated individual moral acts of consumption when aggregated as demand in the

\footnotetext{
${ }^{32}$ J. Boli and G.M. Thomas, 'World Culture in the World Polity: A Century of International Non-Governmental Organization', American Sociological Review, Vol. 62, No. 2 (1997), 171, 172.

${ }^{33}$ See J. Nelson, 'The Operation of Non-Governmental Organizations (NGOs) in a World of Corporate and Other Codes of Conduct', Corporate Social Responsibility Initiative, Working Paper No. 34, Cambridge, MA: John F Kennedy School of Government, Harvard University (2007).

${ }^{34}$ On regulatory capitalism and risk see F. Haines, The Paradox of Regulation: What Regulation Can Achieve and What it Cannot, Cheltenham, Edward Elgar, 2011.
} 
market may have considerable influence on the circumstances of production. The problem is how to meet the costs of organizing this coordination. Individual retailers, it should be noted, also face information and coordination problems. An individual retailer may want to source rugs not made by child labour, but has to find ways to communicate that to consumers, as well as competing with retailers which take no interest in who makes the rugs they sell.

One response to these coordination and information problems has been the rise of standard-setting bodies that create for businesses voluntary standard systems aimed at fulfilling economic, social or environmental goals. Two well-known examples are the Forest Stewardship Council, which was born of a mix of social movements, activists and traders in the 1990s and the Fairtrade Labelling Organizations International (FLO) also established in the 1990s by those who had long fought for better conditions and rewards for poor farmers in developing countries. Certification marks are one critical tool for these organizations. The growth and globalization of organizations designing these voluntary standard setting systems has been rapid. They operate in all sectors of the economy - forestry, fisheries, manufacturing, retail and international trade. ${ }^{35}$ The very process of designing standard systems is itself being standardized with the rise of meta-regulators such as the ISEAL Alliance developing standards for standard-setting. ${ }^{36}$

The rise of these types of organizations has helped to create a world of overlapping circuits of certification in which the certifiers are themselves certified by other certifiers and certifiers are potential competitors. So, for example, FLO-CERT, which is the independent company that certifies producer organizations using FLO standards, is itself certified under the ISO 65, the standard for product certification systems. FLO's standard-setting processes are managed using ISEAL's codes of practice for standard-setting. FLO and GoodWeave both have certification standards

\footnotetext{
${ }^{35}$ For an analysis see M. Chon, 'Marks of Rectitude', Fordham Law Review, 77 (2009), 2311.

${ }^{36}$ On the work of the ISEAL Alliance see http://www.isealalliance.org/.
} 
for rugs, but GoodWeave claims that its system of random inspection gives it a superior system of enforcement. ${ }^{37}$

Competition amongst standard-setting organizations raises possible problems. ${ }^{38}$ The proliferation of competing standards may end up offering companies standards and labels of convenience. For example, many activists who campaigned against the labour practices in Nike's global supply chain saw its decision to join the Fair Labor Association rather than the Workers Rights Consortium as an example of a company moving to lower, corporate friendly standards. ${ }^{39}$ Regulatory capitalism does not stop crises of abuse and death in poor countries, as shown by the more than 1,000 deaths from a fire in a garment-factory building in Bangladesh in April of 2013. But what this kind of tragedy does do is to bring governments, workers, employers, multinational retailers, NGOs into an intense interaction that produces agreements and an array of enforcement strategies based on criminal, economic (threat of trade sanctions, cancellation of contracts) and reputational (exposure of retailers) measures that improve the chances of a woman going into a factory in Bangladesh to make some sweaters coming out alive at the end of her shift.

So far my description of regulatory capitalism seems to bear out Francis Fukuyama's observation that history's end would be dominated by 'economic calculation, the endless solving of technical problems, environmental concerns, and the satisfaction of sophisticated consumer demands'. ${ }^{40}$ However, when we shift our attention to the impact of regulatory capitalism on the earth system, the data suggest that regulatory capi-

\footnotetext{
${ }^{37}$ See http://www.goodweave.org.

${ }^{38}$ See generally L. Fransen, 'Why Do Private Governance Organizations Not Converge? A Political-Institutional Analysis of Transnational Labor Standards Regulation', Governance: An International Journal of Policy, Administration, and Institutions, 24 (2011), 359.

${ }^{39}$ W.L. Bennett and T. Lagos, 'Logo Logic: The Ups and Downs of Branded Political Communication', Annals of the American Academy of Political and Social Science, 611 (2007), 193, 200.

${ }^{40}$ F. Fukuyama, 'The End of History?', available at http://www.wesjones.com/ eoh.htm.
} 
talism is reaching the limits of its adaptive capacity. The International Panel on Climate Change (IPCC) continues to provide evidence of warming of the atmosphere and ocean, changes in global natural cycles, concluding in its latest report that it is 'extremely likely that human influence has been the dominant cause of the observed warming since the mid-20th century'. ${ }^{41}$ The consequences of this form a bleak continuum that ranges from severe to catastrophic. There are more sources of data here than just the IPCC. For example, in 2001 the United Nations launched an initiative known as the Millennium Ecosystem Assessment (MA). ${ }^{42}$ Involving more than 1,360 scientists from 95 countries it produced a series of technical studies and reports that give us the best understanding we have so far of changes in ecosystems and the likely consequences for human well-being. The picture that emerges from the MA is one in which our current state of development has been supported freely by streams of services in the form of clean water, food, disease control, climate regulation and many others emanating, often in hidden ways, from mountain, polar, inland water, coastal, marine, forest, desert and other ecosystems. Economic growth has impacted on these ecosystems to the point where some fifteen out of twenty four of the services provided by these systems are in global decline. ${ }^{43}$

Someone with a lot of faith in regulatory capitalism might argue that it is only a matter of time before regulatory capitalism produces responsive strategies that secure a level of sustainability for the earth system that is consistent with continued human occupation and use of the system. Views about the future cannot be settled until it arrives. My caution about investing faith in the regulatory capacity of today's capitalism lies in the extractive nature of what I take to be its central and driving institution - property rights. One of capitalism's fundamental characteristics is ever higher levels of commodity production and exchange. Drawing on

${ }^{41}$ See 'Approved Summary for Policy-Makers', 27 September 2013, p.12, available at http://www.ipcc.ch/.

${ }^{42}$ See http://www.maweb.org/en/index.aspx.

${ }^{43}$ Millennium Ecosystem Assessment, Ecosystems and Human Well-being: Synthesis, Washington, D.C., Island Press, 2005, 1. 
a distinction made by Marx between use value and exchange value some things, such as eco-systems, have a use value without necessarily having an exchange value. ${ }^{44}$ Capitalism as a system of commodity production relies on property rights in the process of converting things that have use values into commodities i.e. things with exchange values. The best illustration of this process is the way in which the 'commons' is rhetorically characterized as leading to a 'tragedy' of destructive overuse and the solution is seen to lie in its commodification through private property rights. ${ }^{45}$ The commodification solution tends to ignore the history of stateless societies of indigenous peoples. These societies, operating with very different systems of resource control and property to be found in capitalist societies, were not only able to avoid the tragedy of the commons, but in many cases were able to increase their surrounding levels of natural capital. ${ }^{46}$ The commodification solution also overlooks the centrality of the intellectual commons to human creativity and to freedom. ${ }^{47}$

The role of exclusive property rights in capitalist systems of production is generally justified on the basis of some notion of efficiency, either allocative in the case of tangible goods or dynamic in the case of intangible goods. These efficiency arguments ignore a swathe of problems, including the real-world information problems in being able to internalize all externalities through property rights, as well as the presence of transaction costs and unequal distributions of power that disrupt efficient bargaining. As Yoshiyuki Tamura has argued there is a structural bias in

\footnotetext{
${ }^{44}$ For a discussion see B. Fine, Marx's Capital, $2^{\text {nd }}$ edn., Houndmills, Macmillan, 1984, 20-23.

${ }^{45}$ See G. Hardin, 'The tragedy of the commons', Science, 162 (1968), 1243.

${ }^{46}$ See P. Drahos, Intellectual Property, Indigenous people and Their Knowledge, Cambridge, Cambridge University Press, forthcoming 2014.

${ }^{47}$ On the importance of the intellectual commons and the effects of intellectual property on freedom see P. Drahos, A Philosophy of Intellectual Property, Ashgate, Aldershot, 1996; Y. Tamura, 'A Theory of the Law and Policy of Intellectual Property: Building a New Framework', (translated by N. Lee) Nordic Journal of Commercial Law, 1 (2009), available at http://www.njcl.utu.fi/1_2009/ article1.pdf.
} 
favour of the expansion of intellectual property rights, an expansion that is difficult to justify in terms of efficiency. ${ }^{48}$

Capitalism's property solution to the so-called tragedy of the commons is not about saving multi-functional ecological systems, but rather about allowing a particular commodity system such as cattle production to follow an economies-of-scale logic. This economies-of-scale logic heightens rather than lessens the destructive impact of commodity production on vital use values being generated by different kinds of commons. The purpose of property rights in this commodity system is to maximize the rent extraction process or allow a more 'efficient' rent seeker to obtain a market transfer of the resource. Mainstream economics lends ideological legitimacy to these processes by giving very little recognition to the problems of natural resource constraints in devising production functions. $^{49}$

Essentially regulatory capitalism, like other capitalist orders before it, prioritizes exchange value over use value. It is true that regulatory capitalism does more to regulate the process of commodity production, using principles such as polluter pays or through the invention of new managerialist techniques for natural resources. However, as data from the IPCC and the MA, along with many other sources, show the main game is the conversion and degradation of the earth system's use values so that commodity production and exchange can march on. The real tragedy of capitalism has much less to do with the commons and much more to do with unsustainable levels of commodification.

The faithful optimist in the adaptive power of regulatory capitalism might point to some encouraging signs of systems adaptation. The emergence of ecological economics is allowing us to place dollar estimates on the use value of the earth's systems and cycles. So, for example, the coastal wetlands of the US help to protect it from damage from cyclones and hurricanes. Economic modeling suggests that these storm

${ }^{48}$ Y. Tamura, 'A Theory of the Law and Policy of Intellectual Property: Building a New Framework', (translated by N. Lee) Nordic Journal of Commercial Law, 1, 2009, available at http://www.njcl.utu.fi/1_2009/article1.pdf.

${ }^{49}$ H.E. Daly, Ecological Economics and the Ecology of Economics, Cheltenham, UK, Edward Elgar, 1999, 77-78. 
protection services from the wetlands amounts to more than (US) \$23 billion per year, making the preservation of wetlands a highly costefficient exercise. ${ }^{50}$ There are attempt to devise regulatory models for trade in ecological services. ${ }^{51}$ A number of countries have moved towards purchasing defined environmental services that have an environmental goal such as the reduction of the pollution of land or the maintenance of biodiversity. ${ }^{52}$ These are obviously encouraging signs. However, the problems that regulatory capitalism faces at the earth systems level are of a different order to those it has faced in individual industry sectors where it has progressively assembled a track record of, as Malcolm Sparrow puts it, picking important problems and solving them. ${ }^{53}$

\section{Conclusion}

Regulatory capitalism is a distinctive order of capitalism characterized by dense webs of relationships and an array of regulatory techniques in which the state and non-state actors can end up either as regulator or regulatee. The BRICS have in the last decade or so emerged as market powers confronting regulatory domains that have since World War II globalized to a significant degree. As section 3 of the paper suggested the BRICS have entered regulatory orders not of their own making and often under conditions of US and/or EU hegemony. To some extent individually, but clearly collectively they are now in a position to form an

\footnotetext{
${ }^{50}$ See R. Costanza et al, 'The value of coastal wetlands for hurricane protection', AMBIO: A Journal of the Human Environment, 37 (2008), 241.

${ }^{51}$ For an example of a major initiative see The Economics of Ecosystems and Biodiversity: Mainstreaming the Economics of Nature: A synthesis of the approach, conclusions and recommendations of TEEB (2010) available at http:// www.teebweb.org/Portals/25/TEEB\%20Synthesis/TEEB_SynthReport_09_2010 online.pdf.

${ }^{\overline{5}}$ R. Greiner, I. Gordon and C. Cocklin, 'Ecosystem Services From Tropical Savannas: Economic Opportunities Through Payments for Environmental Services', Rangeland Journal, 31 (2009), 51, 56.

${ }^{53}$ M. Sparrow, The Regulatory Craft: Controlling Risks, Solving Problems, and Managing Compliance, Washington D.C., The Brookings Institution, 2000, 9.
} 
effective veto coalition to global regulatory agendas coming out of the US or EU. They have yet to translate their economic power into the networked hard and soft power that has seen the US state and US multinationals be such effective actors of global regulatory change. In the area of global financial regulation there is an urgent need for approaches that shift regulatory capitalism way from the instabilities being generated by US crony financialism. For the moment the BRICS can at best be described as taking modest steps in this direction.

In section 4, I suggest that regulatory capitalism may represent the end of history, but not quite in the sense intended by Fukuyama. My central contention in this part of the paper is that addressing the problems of the earth system will require much more than the smart use of regulatory techniques. These techniques will not of themselves be enough to prevent the tragedies of commodification, the shadows of which loom ever larger. What is also needed is for us to re-think the operation of capitalism's most fundamental institution - property. Whether the rise of the BRICS will help to bring about such a revolutionary process is hard to say. No doubt there will be much criticism of my claim, as well as different ideas on how to begin the task of re-thinking property. My own view is that we need to study more closely the idea of a property cosmos in which conditional permissions play a much more central role than exclusive rights. Examples and variants of such a property cosmos are to be found in the indigenous societies of Australia, societies that were able to adapt to the great droughts and ice ages that occurred during their 50,000 year occupation of Australia. Central to this extraordinarily long period of continuous occupation was the way in which these indigenous societies were able to integrate cosmology and property. ${ }^{54}$

\footnotetext{
54 This is a key argument of P. Drahos, Intellectual Property, Indigenous people and Their Knowledge, Cambridge, Cambridge University Press, forthcoming 2014.
} 